\title{
MECHANICAL AND TRIBOLOGICAL PROPERTIES OF NANOFILLED PHENOLIC-MATRIX LAMINATED COMPOSITES
}

\author{
MEHANSKE IN TRIBOLOŠKE LASTNOSTI FENOLNIH MATRIC V \\ KOMPOZITIH, PRIDOBLJENIH Z NANOTEHNOLOGIJO
}

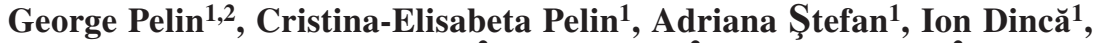 \\ Ecaterina Andronescu ${ }^{2}$, Anton Ficai ${ }^{2}$, Roxana Trușcă ${ }^{2}$ \\ ${ }^{1}$ National Institute for Aerospace Research - Elie Carafoli, 220 Iuliu Maniu Blvd, 061126 Bucharest, Romania \\ ${ }^{2}$ University Politehnica of Bucharest, Faculty of Applied Chemistry and Materials Science, 1-7 Gh. Polizu St., 011061 Bucharest, Romania \\ ban.cristina@incas.ro \\ Prejem rokopisa - received: 2016-01-17; sprejem za objavo - accepted for publication: 2016-10-24
}

doi: $10.17222 /$ mit. 2016.013

Phenolic-resin composites have attractive properties for applications in various fields from the wood and adhesive industry to the automotive, aeronautics and aerospace industries. The paper presents the obtaining of SiC-nanofilled phenolic-resin-based composites reinforced with a bidimensional fabric. Different contents of nanometric silicon carbide $(0.5,1$ and 2$) \%$ mass fractions) were dispersed into the phenolic-resin matrix, using the ultrasonication method, to ensure the optimum dispersion. Several layers of the bidimensional fabric were impregnated with the obtained mixtures and the final laminated composites were obtained using high-temperature pressing, followed by a multistage temperature program. The obtained laminated nanocomposites were characterized with FTIR spectroscopy and evaluated in terms of mechanical and tribological properties. After mechanical testing, fracture cross-sections were characterized with SEM and optical microscopy. The results highlight the positive effect of the nanometric silicon-carbide addition to the phenolic-resin matrix of the laminated composites, in terms of mechanical and tribological performance, improving their strength, stiffness and abrasive properties.

Keywords: laminated composites, tensile strength, flexural strength, nanometric silicon carbide, nanocomposites, friction coefficient

Kompoziti fenolnih smol imajo možnosti raznovrstne uporabe na različnih področjih, tako na področju lesne industrije, v industriji lepil, kot v avtomobilski in letalski industriji. Prispevek predstavlja pridobitev SiC fenolnih kompozitov na osnovi smole, ojačanih z bidimenzionalnimi vlakni. Različne vsebine nanosilicijevega karbida $(0,5,1$ in 2$) \%$ masnega odstotka, so bile razpršene $\mathrm{z}$ uporabo ultrazvočne metode $\mathrm{v}$ matrici, pridobljeni s smolo, da je bila zagotovljena optimalna disperzija. Več plasti bidimenzionalnih vlaken je bilo impregniranih s pridobljenimi mešanicami in končni laminirani kompoziti so bili pridobljeni $z$ visokotemperaturnim tlačnim pritiskanjem, kateremu je sledil večstopenjski temperaturni program. Pridobljeni laminirani kompoziti so bili preučevani s FTIR-spektroskopijo in ovrednoteni glede na mehanske in tribološke lastnosti. Presek zloma po mehanskem testiranju je bil preučevan s SEM-mikroskopijo in optično mikroskopijo. Rezultati kažejo pozitiven učinek dodatka nanometričnih silicijevih karbidov, s smolo pridobljenih matric v večplastnih kompozitih, zaradi njihovih mehanskih in triboloških lastnosti, in ker se tako izboljša moč, togost in abrazivne lastnosti.

Ključne besede: laminirani kompoziti, natezna trdnost, upogibna trdnost, nanosilicijevi karbidi, nanokompoziti, koeficient trenja

\section{INTRODUCTION}

Due to their high strength and rigidity combined with low density, fiber-reinforced polymeric composites (FRP) are extensively used in a wide variety of fields, from sports equipment ${ }^{1-2}$ to the automotive, civil engineering, ${ }^{3-5}$ military, ${ }^{6-7}$ aeronautics and aerospace ${ }^{8-10}$ industries. The oldest thermoset polymers are phenolic resins. This type of resins are mostly used as heat insulation in aerospace applications, due to their low cost and facile processability ${ }^{11}$ as well as their attractive properties such as chemical, heat and friction resistance and superior thermal insulation characteristics. ${ }^{12}$ They are generally used in combination with other materials such as powder fillers and short or long fiber reinforcements. Phenolic-resin-impregnated fibers (glass, carbon, aramid) result in phenolic-resin-laminated composites and are mostly formed with compression molding. ${ }^{12-13}$ During the obtaining process of this kind of materials, vola- tile-compound management is crucial in producing high-quality laminates. ${ }^{14}$ An efficient management of volatile compounds during the development stage of phenolic-resin/fiber laminates leads to void-free composites and, consequently, fewer stress-concentration sites that contribute to creating a stronger interface. The fiber/matrix interface is a decisive factor for the final mechanical and physical properties of the composite materials. ${ }^{15}$

Composite materials based on phenolic resins/carbon fibers have been used by NASA as the standard material for high-temperature applications. These composites have different micronic fillers added to the matrix for the stabilization of charred polymer during the combustion. ${ }^{16}$ However, the use of nanofillers instead of the micronic ones allows a weight reduction in the aerospace systems, and it also leads to thinner protection layers with better ablative properties. ${ }^{16}$ Studies show that mechanical, thermal and friction properties of phenolic-matrix/fiber com- 
posites can be improved by adding nanometric fillers such as carbon nanotubes, ${ }^{17-18}$ layered silicates (nanoclays), ${ }^{19}$ POSS compounds, ${ }^{20}$ silica ${ }^{21-22}$ or silicon carbide $^{23-25}$ to the phenolic resin. In the case of carbon-phenolic composites with nanoclays, studies show that higher nanoclay contents decrease the erosion rate, surface temperature and insulation index, ${ }^{26}$ and can improve some properties, such as the flexural strength, stiffness and glass-transition temperature. ${ }^{27}$ On the contrary, there are studies that report a decrease in the flexural strength and stiffness. ${ }^{16}$ Literature also presents studies that examine the effect of montmorillonite nanoclays on the mechanical and morphological characteristics of the glassfiber-reinforced composites based on the novolac phenol- formaldehyde matrix, showing that a nanoclay addition enhances the mechanical properties when a strong matrix-fiber interface is observed. ${ }^{11}$

The other interesting nanofiller is silicon carbide $(\mathrm{nSiC})$ that is mostly used to improve the thermo-oxidative resistance ${ }^{25}$ and wear resistance ${ }^{23-24}$ of carbon/phenolic ablative materials. However, literature reports no studies involving carbon- and/or glass-fiber-fabric-laminated composites based on the nSiC-modified phenolic resin. The aim of this study is the evaluation of the effect of a silicon-carbide nanofiller addition to the phenolic-resin matrix of carbon- and glass-fabric-reinforced composites, taking into consideration morphological, mechanical and tribological properties. The paper presents the obtaining of nanometric silicon-carbide-filled phenolic-resin-matrix composites reinforced with glass or carbon-fiber bidimensional fabric. The obtained laminates based on different nanofiller contents were characterized in terms of chemical, mechanical and tribological properties. The results highlighted the positive effect of $\mathrm{nSiC}$ on the laminated composites, when added in the optimum weight content relative to the phenolic-resin matrix.

\section{EXPERIMENTAL PART}

\subsection{Materials}

The matrix used was the resole-type phenolic resin ISOPHEN 215 SM $57 \%$ (PR) provided by ISOVOLTA S.A. Bucharest, with a density of $1135 \mathrm{~g} / \mathrm{cm}^{3}$. The nanofiller used was the $\beta$-type nanometric silicon carbide $(\mathrm{nSiC})$ purchased from Nanostructured \& Amorphous

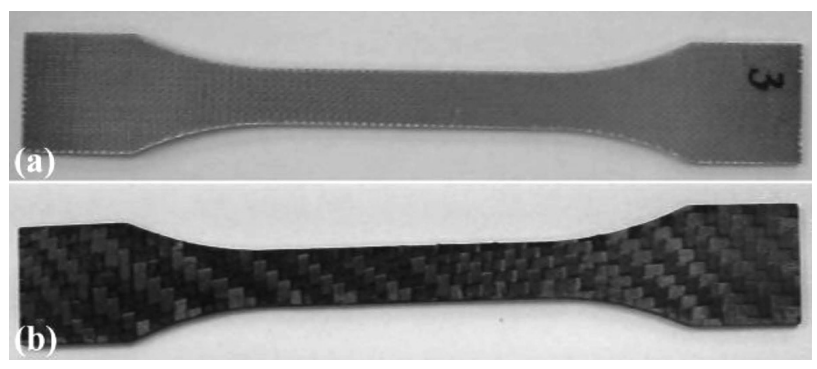

Figure 1: a) glass-fiber and b) carbon-fiber-PR-based composites; specimens for tensile tests
Materials Inc., USA, with the following characteristics: a purity of $97.5 \%$, the average particle size of $45-55 \mathrm{~nm}$, the specific surface area of $34-40 \mathrm{~m}^{2} / \mathrm{g}$ and true density of $3.22 \mathrm{~g} / \mathrm{cm}^{3}$. The reinforcing materials were the carbon fiber (CARP/T 193, produced by Chemie Craft, France) and E-glass-fiber bidimensional fabrics.

\subsection{Method for obtaining nanofilled-laminated com- posites}

The development of the nanofilled-laminated composites was a 3 -stage process. The first stage consisted of $\mathrm{nSiC}$ additions of different contents $(0,0.5,1$ and 2$) \%$ of mass fractions to the phenolic resin (PR), bulk homogenization achieved with mechanical stirring for approx. $5 \mathrm{~min}$ and nanofiller dispersion carried out with the ultrasonication technique, using a Bandelin Sonopuls probe for $15 \mathrm{~min}$. In the second stage, 5 layers of carbon fiber (CF) and glass fiber (GF), respectively, were impregnated with the obtained mixtures. The soaked layers were maintained at $25^{\circ} \mathrm{C}$ for $30 \mathrm{~h}$ for a better impregnation, then they were subjected to methanol-solvent elimination at $70{ }^{\circ} \mathrm{C}$ for $30 \mathrm{~min} .{ }^{28}$ The final stage was the heat-curing process that took place under pressure using a CARVER hydraulic press. Along with pressing, the temperature was raised from $25{ }^{\circ} \mathrm{C}$ to $150{ }^{\circ} \mathrm{C}$ at a $30{ }^{\circ} \mathrm{C} / \mathrm{min}$ heating rate, followed by a $30 \mathrm{~min}$ dwell period at $150{ }^{\circ} \mathrm{C}$ and cooling under pressure down to room temperature. Laminated composite plates were obtained; from them, dumbbell and rectangular specimens for mechanical and tribological tests were cut. Figure 1 shows two of the specimens used for tensile tests, illustrating the dumbell geometry.

\subsection{Characterization techniques}

The phenolic-based nanocomposite laminates were subjected to a spectroscopy analysis using a Nicolet iS50 spectrometer (operated in the ATR mode) and scanning electron microscopy (SEM) using a QUANTA INSPECT $\mathrm{F}$ microscope with a field emission gun and $1.2 \mathrm{~nm}$ resolution, and an energy-dispersive X-ray spectrometer (EDS). The materials were tested in terms of mechanical performance with an INSTRON 5982 machine. The tensile tests carried out on dumbbell specimens were performed according to SR EN ISO 527-2 29 using a $5 \mathrm{~mm} / \mathrm{min}$ tensile rate, while flexural (3-point bending) tests carried out on rectangular specimens were performed according to SR EN ISO $14125^{30}$ using a $2 \mathrm{~mm} / \mathrm{min}$ speed, conventional deflection and the nominal span length $(16 \times$ the specimen thickness). Tribological tests were performed using CETR UMT 3 (Universal Macro Materials Tester) - the block-on ring module - on a $35 \mathrm{~mm}$ (diameter) $\times 11 \mathrm{~mm}$ (width) stamped steel roller (A4138 Timken outer rolling bearing ring), in the counterclockwise testing direction under a $10 \mathrm{~N}$ normal force, using samples with dimensions of $16 \mathrm{~mm}$ (length) $\times 6.5 \mathrm{~mm}($ width $) \times 2$ (thickness $) \mathrm{mm}$. A 
test was performed for $60 \mathrm{~s}$ using two different rotation speeds: $1000 \mathrm{~min}^{-1}(1.75 \mathrm{~m} / \mathrm{s})$ and $1500 \mathrm{~min}^{-1}(2.62 \mathrm{~m} / \mathrm{s})$. The tests were conducted on a minimum of 3 specimens per sample, at the standard atmospheric conditions, ( $25^{\circ} \mathrm{C}$ and $45-55 \%$ relative humidity).

\section{RESULTS AND DISCUSSION}

\subsection{FTIR-spectroscopy}

The nanofilled phenolic matrix of the laminated composites was subjected to FTIR spectroscopy analyses after polishing the analyzed area. The nanofilled-matrix-based laminated composite samples were compared with the control sample to evaluate the interactions between $\mathrm{nSiC}$ and the phenolic resin that could generate peak-position shifting and/or peak-intensity variations. Figure 2 presents the spectra of the $\mathrm{nSiC}$ nanofiller powder and simple nSiC-filled phenolic resin from the laminated composites; all the composite samples present the characteristic peaks of the cured resin. The peak at $3290 \mathrm{~cm}^{-1}$ corresponds to the $\mathrm{OH}$ stretching from resole, the one at $2920 \mathrm{~cm}^{-1}$ is due to the $\mathrm{CH}_{2}$ stretching, while the peaks in the $1600-1470 \mathrm{~cm}^{-1}$ range are due to the $-\mathrm{C}=\mathrm{C}$ stretching in the aromatic ring. The $\mathrm{CH}_{2}$ bending vibration generated the peaks at $1435 \mathrm{~cm}^{-1}$ and $1330 \mathrm{~cm}^{-1}$, the $\mathrm{C}-\mathrm{O}$ stretching at approximately $1190 \mathrm{~cm}^{-1}$ and the C-O-C stretching at $998 \mathrm{~cm}^{-1}{ }^{31}$ The 3 peaks between $900-600 \mathrm{~cm}^{-1}$ are due to ortho-disubstituted, meta-disubstituted and monosubstituted benzenes. ${ }^{31-32}$ The meta-disubstituted benzene peak at $815 \mathrm{~cm}^{-1}$ overlaps with the $\mathrm{nSiC}$ characteristic peak, assigned to the $\mathrm{Si}-\mathrm{C}$ vibration that appears at approximately $800-815 \mathrm{~cm}^{-1}{ }^{33-34}$ so that the $\mathrm{nSiC}$ presence is more difficult to highlight. However, it is noticed that the peak intensity increases with the $\mathrm{nSiC}$ content in the PR matrix of the laminated composites, which could be due to the higher $\mathrm{nSiC}$ content interacting with the phenolic resin. ${ }^{35}$ The absorption of a diamond crystal generates a noise between 1900-2300 $\mathrm{cm}^{-1}$, which, therefore, must be ignored.

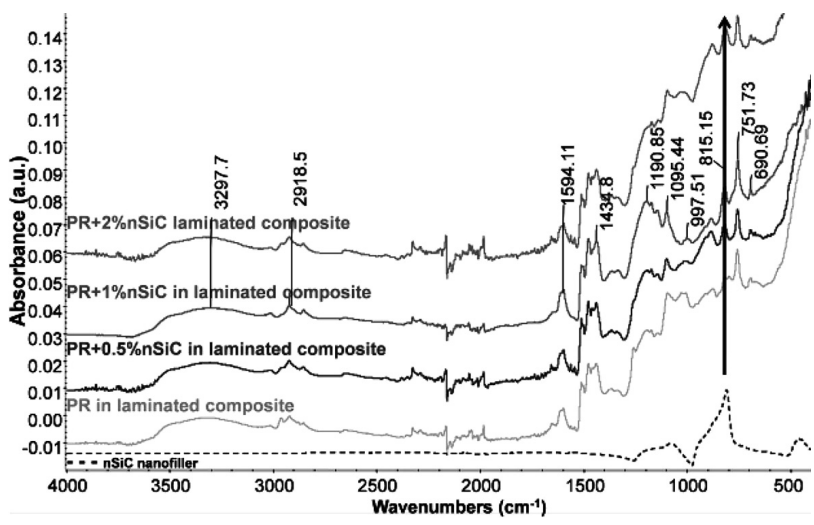

Figure 2: FTIR spectra of PR and nSiC/PR from the laminated composites

\subsection{SEM analysis}

A SEM analysis was performed on the fracture cross-sections of the mechanically tested laminated samples to evaluate the fiber/matrix interface at high magnification levels. SEM images of carbon and glass-fabric-based control samples (Figure 3a to $\mathbf{3 c}$ ) illustrate that the resin did not embed the entire surface of the fibers that the fabric is made of, and that the stress induced during the mechanical testing generated both a detachment of the polymer from the fibers as well as the matrix micro-cracking. In the case of the $1 \% \mathrm{nSiC}$-filled matrix, it can be observed that the polymer layer covering the fibers is more compact, suggesting that the matrix was able to undergo the mechanical stress without being subjected to a detachment or micro-cracking. This could be due to the strengthening of the matrix caused by the $\mathrm{nSiC}$ presence that, along with a proper fiber/matrix interface, helps sustain a better mechanical load transfer within the composite. Figure 4 illustrates high-magnification images of the samples with $1 \%$ and $2 \% \mathrm{nSiC}$ contents added to the phenolic resin of the carbon-fiber-reinforced composites. A higher agglomeration tendency of the nanoparticles can be observed in the samples with a higher $\mathrm{nSiC}$ content. Also, in the case of $5 \mathrm{CF} / \mathrm{PR}+1 \% \mathrm{nSiC}$ (Figure 4a) the polymer layer uniformly covers the fiber surface, embedding the nanoparticles, while in the case of $5 \mathrm{CF} / \mathrm{PR}+2 \% \mathrm{nSiC}$ (Figure 4b) the agglomerated nanoparticles produce voids around that area. The areas composed of voids and agglomerated nanoparticles can act as stress-concentration sites, sustaining crack propagation, which influences the mechanical behavior.

\subsection{Mechanical testing}

The mechanical-performance evaluation was done through tensile and three-point bending tests. Mechani-

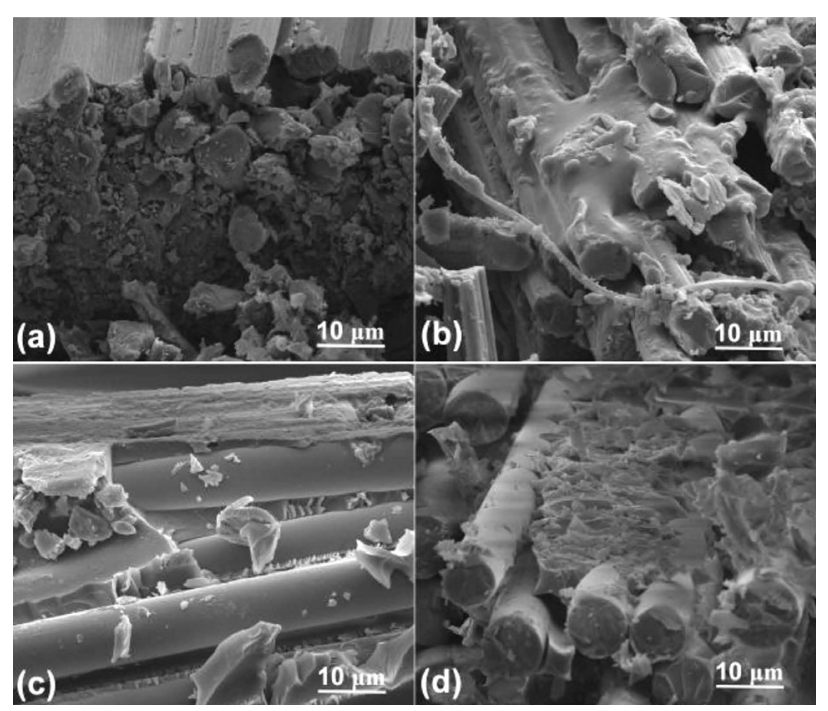

Figure 3: SEM images of: a) $5 \mathrm{CF} / \mathrm{PR}$, b) $5 \mathrm{CF} / \mathrm{PR}+1 \% \mathrm{nSiC}$, c) $5 \mathrm{GF} / \mathrm{PR}$, d) $5 \mathrm{GF} / \mathrm{PR}+1 \% \mathrm{nSiC}$ 
G. PELIN et al.: MECHANICAL AND TRIBOLOGICAL PROPERTIES OF NANOFILLED PHENOLIC-MATRIX ...

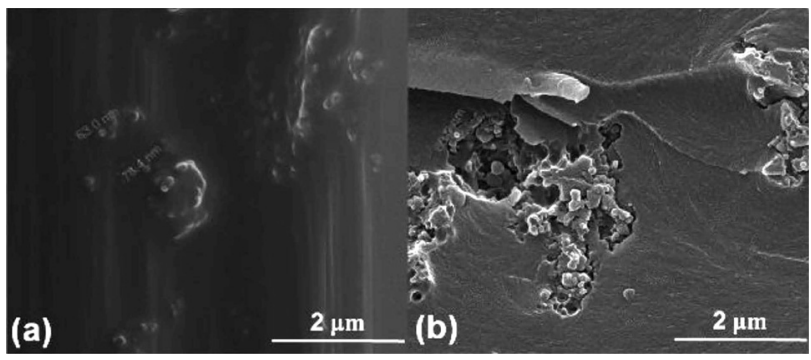

Figure 4: High-magnification SEM images of: a) $5 \mathrm{CF} / \mathrm{PR}+1 \% \mathrm{nSiC}$, b) $5 \mathrm{CF} / \mathrm{PR}+2 \% \mathrm{nSiC}$

cal test results (Table 1) show the fact that an $\mathrm{nSiC}$ addition to the phenolic-resin matrix significantly improves the mechanical performance of both carbon- and glass-fiber-reinforced laminated composites. Overall, all the nanofilled samples exhibited higher strength and stiffness compared with the control samples.

Table 1: Mechanical properties of nSiC-filled 5CF/PR and 5GF/PR laminated composites

\begin{tabular}{|c|c|c|c|c|c|c|}
\hline $\begin{array}{c}\text { nSiC } \\
(w / \%)\end{array}$ & $\begin{array}{c}\text { Tensile } \\
\text { strength } \\
(\mathrm{MPa})\end{array}$ & $\begin{array}{c}\text { Tensile } \\
\text { modulus } \\
(\mathrm{GPa})\end{array}$ & $\begin{array}{c}\text { Tensile } \\
\text { strain } \\
(\%)\end{array}$ & $\begin{array}{c}\text { Flexural } \\
\text { strength } \\
(\mathrm{MPa})\end{array}$ & $\begin{array}{c}\text { Flexural } \\
\text { modulus } \\
(\mathrm{GPa})\end{array}$ & $\begin{array}{c}\text { Elonga- } \\
\text { tion }(\%)\end{array}$ \\
\hline \multicolumn{7}{|c|}{ 5CF/PR based laminated composites } \\
\hline 0 & 318.0 & 47.8 & 0.8 & 382.1 & 43.9 & 1.22 \\
\hline 0.5 & 344.5 & 50.5 & 0.75 & 420.3 & 48.6 & 1.09 \\
\hline 1 & 384.5 & 68.6 & 0.7 & 458.0 & 56.3 & 1.04 \\
\hline 2 & 331.9 & 52.9 & 0.48 & 440.2 & 45.0 & 1.02 \\
\hline \multicolumn{7}{|c|}{ 5GF/PR based laminated composites } \\
\hline 0 & 300.3 & 22.0 & 2.02 & 350.7 & 27.4 & 2.41 \\
\hline 0.5 & 314.3 & 27.1 & 0.83 & 363.2 & 32.7 & 1.29 \\
\hline 1 & 342.5 & 37.5 & 0.77 & 423.6 & 34.6 & 1.23 \\
\hline 2 & 293.3 & 22.1 & 0.71 & 352.0 & 33.3 & 1.17 \\
\hline
\end{tabular}

The same trend was observed in both carbon- and glass-fiber laminates in terms of the $\mathrm{nSiC}$-content effect. The highest results were exhibited by the samples based on the $1 \% \mathrm{nSiC}$-filled matrix, in the case of 5CF/PR, where the $1 \%$ content samples showed an increase of $20 \%$ in the tensile and flexural strength and an increase of $30-40 \%$ in the tensile and flexural modulus, while for $5 \mathrm{GF} / \mathrm{PR}$, the $1 \%$ nanofiller led to an increase of $15-20 \%$ in the tensile and flexural strength and an increase of $30-70 \%$ in the tensile and flexural modulus. The nanoparticles embedded into the phenolic-resin matrix that covers the fibers (Figure 4a) could act as a crack-propagation hindering agent, enhancing the matrix strength and stiffness and, consequently, the mechanical properties of the laminated composite based on this matrix. This phenomenon was observed also in the case of phenolic-resin $/ \mathrm{nSiC}$ nanocomposites presented in a previous study. ${ }^{35}$ At higher contents $(2 \%)$, the properties decrease compared to $1 \%$, probably due to the existent nanofiller agglomeration, showed by SEM images (Figure $4 \mathbf{b}$ ), that could lead to stress-concentration sites and/or crack-initiation sites that sustain earlier mechani- cal failures and contribute to the decrease in the mechanical-properties.

In both tensile and flexural tests, elongation decreases with the $\mathrm{nSiC}$ content increase due to the brittle nature of $\mathrm{nSiC}$ that enhances the composite rigidity.

\subsection{Fractography}

Fractography represents the fracture-mode analysis through light microscopy. Being an important tool in a material investigation related to a failure analysis and quality control, ${ }^{36}$ light microscopy was the main method used to analyze the damage after the mechanical testing and to establish the failure mode type and mechanism. Light microscopy was the first method used to investigate the failure mode as it allows a visualization of the entire fractured area along the whole length of a sample. Figure 5 illustrates the fractured areas of the representative specimens of laminated composite samples. Both carbon- and glass-fiber-based composites showed the same behavior as the $\mathrm{nSiC}$ content in the phenolic matrix. All the samples exhibited a certain degree of delamination, generated by crack propagation. While the control samples (Figure 5a and 5e) and the PR-matrix laminates including $0.5 \% \mathrm{nSiC}$ (Figure $\mathbf{5 b}$ and $\mathbf{5 f}$ ) showed more extended delaminated areas, the $1 \%$ nSiC-content-based sample showed the lowest delamination degree in both carbon and glass-fabric laminates

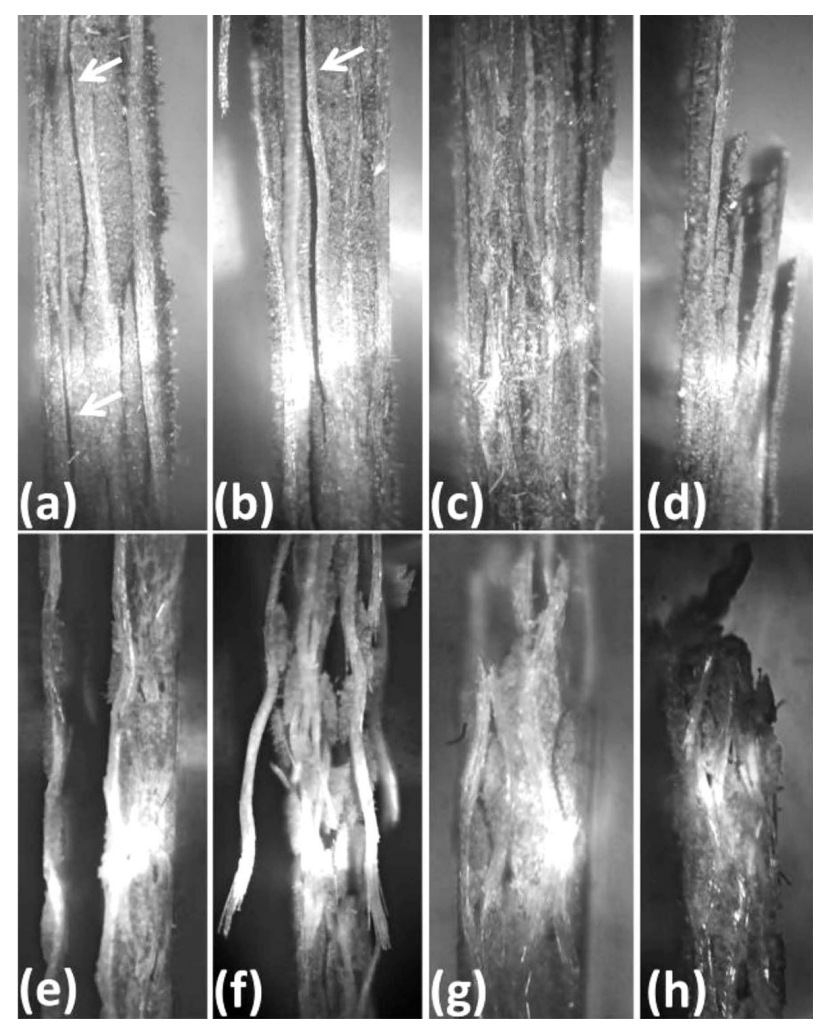

Figure 5: Optical-microscopy images of the tensile-test specimens: a), b), c), d) 5CF/PR+ 0; 0.5; 1;2 \% nSiC and e), f), g), h) 5GF/PR+ 0; $0.5 ; 1 ; 2 \% \mathrm{nSiC}$ 
(Figure $\mathbf{5 c}$ and $\mathbf{5 g}$ ), where only the external layers exhibited detachment.

In the case of the $2 \% \mathrm{nSiC}$ laminates (Figure $\mathbf{5} \mathbf{d}$ and $\mathbf{5 h}$ ), all the fabric layers ruptured after the tensile testing, showing delaminated layers only in the fracture regions.

The optical-microscopy method was further supported with higher-magnification images of the fracture cross-sections, captured with SEM (Figure 6). Optical-microscopy images provide valuable information when choosing the most appropriate locations to be visualized with scanning electronic microscopy. ${ }^{36}$ SEM images of the entire fracture cross-sections of the samples show that the control samples (Figure 6a and $\mathbf{6 c}$ ) were subjected to a higher damage extent; delaminated areas are still visible on the $0.5 \% \mathrm{nSiC}$-based sample (Figure 6b), while the image of the $1 \% \mathrm{nSiC}$ sample (Figure 6d) suggests that the fabric-layer fracture occurred due to the strain and that the fibers broke on the same fracture section line.

\subsection{Tribological testing}

The positive effect of the $\mathrm{nSiC}$ addition was also reflected on the tribological test results. The laminated composites were tested at two speed rates: $1000 \mathrm{~cm}^{-1}$ $(1.75 \mathrm{~m} / \mathrm{s})$ and $1500 \mathrm{~cm}^{-1}(2.62 \mathrm{~m} / \mathrm{s})$, on a minimum of three specimens per sample, over a short period of time (60 s) to evaluate the friction-coefficient trend at the initial stage of the friction-force action. Figure 7 and Figure 8 illustrate the friction-coefficient function of the $\mathrm{nSiC}$ weight content in the matrix of the carbon- and glass-fabric-laminated composites. It can be observed that there is a significant increase in the friction coefficient with a nanofiller content increase in the matrix, where substantial increments are obtained at the higher testing speed.

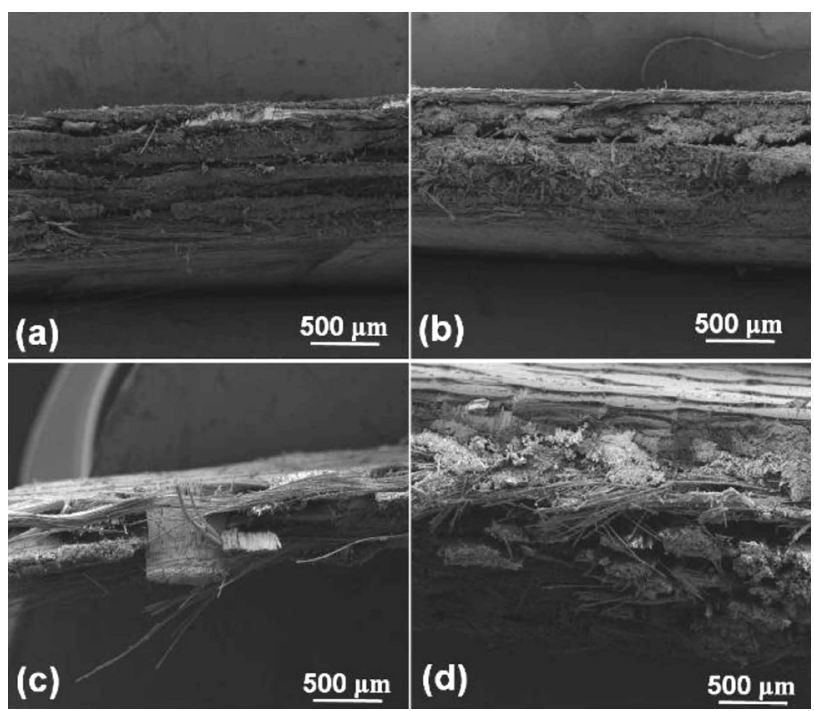

Figure 6: SEM images of fracture cross-sections of: a) $5 \mathrm{CF} / \mathrm{PR}$, b) $5 \mathrm{CF} / \mathrm{PR}+0.5 \% \mathrm{nSiC}$, c) $5 \mathrm{GF} / \mathrm{PR}$, d) $5 \mathrm{GF} / \mathrm{PR}+1 \% \mathrm{nSiC}$

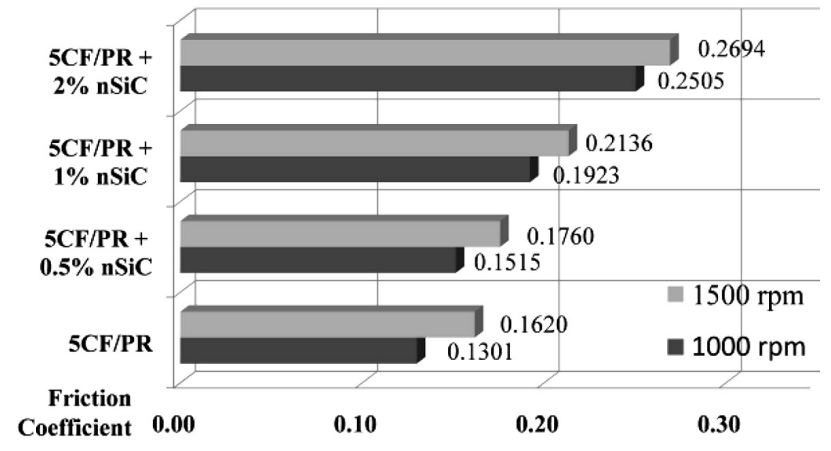

Figure 7: Friction-coefficient values for $5 \mathrm{CF} / \mathrm{PR} / \mathrm{nSiC}$ composites

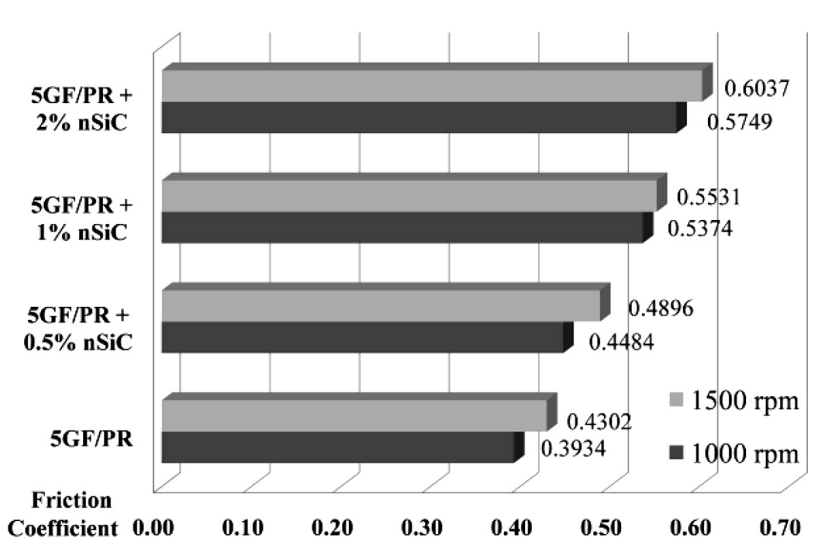

Figure 8: Friction-coefficient values for $5 \mathrm{GF} / \mathrm{PR} / \mathrm{nSiC}$ composites

In the case of carbon-fiber-based composites, the friction coefficient increases by approximately 10-16\% when adding $0.5 \% \mathrm{nSiC}, 30-50 \%$ for $1 \% \mathrm{nSiC}$ and $70-90 \%$ for the $2 \%$ nanofiller compared with the control sample.

For glass-fiber-based composites, the friction-coefficient increments are not as significant as in the case of carbon fiber, as $\mathrm{nSiC}$ generates an increase of $14 \%$ in the case of the $0.5 \%$ addition, $30-37 \%$ in the case of the $1 \%$ addition and $40-45 \%$ in the case of the $2 \%$ addition.

The differences between the GF- and CF-based samples regarding the friction-coefficient values are due to different tribological characteristics of the two fiber types, where the carbon fiber is an anti-friction material $^{37}$, while the glass fiber promotes friction. ${ }^{38}$

\section{CONCLUSIONS}

The paper presents the obtaining and characterization of glass- or carbon-fiber bidimensional, reinforced composites based on the phenolic-resin matrix with different nSiC contents. The obtained results showed that the addition of nanometric silicon carbide improved the tensile and flexural strength and the modulus of the laminated composites, and that the best results were obtained with the $1 \%$ mass fractions of the nanofiller contents for both carbon- and glass-fiber-reinforced composites. The ten- 
sile and flexural strength increased by $15-20 \%$ with the $1 \% \mathrm{nSiC}$ content in the PR matrix for both glass- and carbon-fiber-reinforced composites, while the tensile and flexural modulus increased by $30-40 \%$ for the carbon-fiber and 20-30\% for the glass-fiber composites.

In terms of the tribological behavior, the friction coefficient increased with the nanofiller-content increase. For the glass-fiber-based composites, nSiC generated an increase of 30-37\% when the $1 \%$ content was added and an increase of $40-45 \%$ for the $2 \%$ weight contents. In the case of the carbon-fiber-based composites, the control sample had a very low friction coefficient (0.13); therefore, the nanofilled sample's friction coefficient increased significantly: by $30-50 \%$ for $1 \% \mathrm{nSiC}$ and by $70-90 \%$ for the $2 \%$ nanofiller. It was observed that higher speed rates led to higher friction-coefficient values.

The results highlight that $1 \% \mathrm{nSiC}$ by weight is the optimum content for phenolic/fabric composites in order to obtain both the maximum mechanical and tribological improvements as, at this content, the optimum nanoparticle embedment into the phenolic resin is achieved.

\section{Acknowledgments}

The work was funded by the Sectorial Operational Programme Human Resources Development 2007-2013 of the Ministry of European Funds through the Financial Agreement POSDRU/159/1.5/S/134398.

\section{REFERENCES}

${ }^{1}$ T. Johnson: Applications of carbon fiber - what products use carbon fiber today, Composite.about.com, http://composite.about.com/od/ aboutcarbon/a/Applications-Of-Carbon-Fiber.htm, 27.10.2015

${ }^{2}$ T. Johnson, Carbon fiber in sports, Composite.about.com, http://composite.about.com/od/aboutcarbon/a/Carbon-Fiber-In-Sports.htm, 29.10.2015

${ }^{3}$ N. E. Chikh, B. Bousalem, M. Gahmous, N. Djebbar, T. Zarza, R. Renzaid, Use of FRP composites in civil engineering structural applications, Proc. du Colloque Méditerranéen sur les Matériaux, Cmedimat, Algeria, 2005

${ }^{4}$ D. R. Mertz, Application of fiber reinforced polymer composites to the highway infrastructure - Report 503, National Cooperative Highway Research Program, Washington, US, 2003, http://onlinepubs. trb.org/onlinepubs/nchrp/nchrp_rpt_503.pdf, 3.12.2015

${ }^{5}$ J. Bai, Advanced fibre-reinforced polymer (FRP) composites for structural applications, 1st ed., Woodhead Publishing, Oxford, 2013, 928

${ }^{6} \mathrm{P}$. K. Mallick, Introduction - aircraft and military application, in: Fiber-Reinforced Composites, Materials, Manufacturing, and Design, CRC Press Taylor \& Francis Group, New York 2007, 24-29

${ }^{7}$ L. A. Pilato, M. J. Michno, Advanced Composite Materials, Springer Science \& Business Media, Berlin 1994, 208

${ }^{8} \mathrm{~J}$. Li, Effect of fiber surface treatment on wear characteristics of carbon fiber reinforced polyamide 6 composites, Iran. J. Chem. Chem. Eng., 29 (2010) 1, 141-147

${ }^{9}$ N. Chand, M. Fahim, An introduction to tribology of FRP materials, Allied Publishers, New Delhi, 2000, 299

${ }^{10}$ P. E. Irving, C. Soutis, Polymer composites in the aerospace industry, Woodhead Publishing, Cambridge, 2014, 536
${ }^{11}$ M. Eesaee, A. Shojaei, Effect of nanoclays on the mechanical properties and durability of novolac phenolic resin/woven glass fiber composite at various chemical environments, Compos. Part A, 63 (2014) August, 149-158, doi:10.1016/j.compositesa.2014.04.008

${ }^{12}$ N. Winya, S. Chankapoe, C. Kiriratnikom, Ablation, mechanical and thermal properties of fiber/phenolic matrix composites, International Journal of Chemical, Molecular, Nuclear, Materials and Metallurgical Engineering, 6 (2012) 9, 875-878, doi:10.1016/S1359835X(01)00092-6

${ }^{13}$ N. Winya, A. Boonpan, K. Prapunkarn, Study of factors affecting the ablation rate of phenolic resin/fiber glass, International Journal of Chemical Engineering and Applications, 4 (2013) 4, 234-237, doi: 10.7763/IJCEA.2013.V4.302

${ }^{14}$ T. H. Hou, J. M. Bai, J. M. Baughman, Processing and properties of a phenolic composite system, NASA Technical Report LAR-16877-1, 2006, http://ntrs.nasa.gov/archive/nasa/casi.ntrs.nasa.gov/20080014267. pdf, 6.1 .2016

${ }^{15}$ M. A. Hayat, S. M. A. Suliman, Mechanical and structural properties of glass reinforced phenolic laminates, Polym. Test., 17 (1998) 2, 79-97, doi: 10.1016/S0142-9418(97)00019-6

${ }^{16}$ L. Asaro, G. Rivero, L. B. Manfredi, V. A. Alvarez, E. S. Rodriguez, Development of carbon fiber/phenolic resin prepregs modified with nanoclays, J. Compos. Mater., 5 (2015), 1-14, doi:10.1177/ 0021998315590866

${ }^{17}$ M. Natali, M. Monti, D. Puglia, J. M. Kenny, L. Torre, Ablative properties of carbon black and MWNT/phenolic composites: a comparative study, Compos. Part A, 43 (2012) 1, 174-182, doi:10.1016/ j.compositesa.2011.10.006

${ }^{18}$ M.-K. Yeh, N.-H. Tai, Y.-J. Lin, Mechanical properties of phenolic-based nanocomposites reinforced by multi-walled carbon nanotubes and carbon fibers, Compos. Part A, 39 (2008) 4, 677-684, doi:10.1016/j.compositesa.2007.07.010

${ }^{19}$ A. R. Bahramian, M. Kokabi, Ablation mechanism of polymer layered silicate nanocomposite heat shield, Hazardous Materials, 166 (2009) 1, 445-454, doi:10.1016/j.jhazmat.2008.11.061

${ }^{20}$ J. H. Koo, M. Natali, J. S. Tate, E. Allcorn, Polymer nanocomposites as ablative materials - a comprehensive review, International Journal of Energetic Materials and Chemical Propulsion, 12 (2013) 2, 119-162, doi:10.1615/IntJEnergeticMaterialsChemProp.2013005383

${ }^{21}$ M. Natali, M. Monti, J. Kenny, L. Torre, Synthesis and thermal characterization of phenolic resin/silica nanocomposites prepared with high shear rate-mixing technique, J. Appl. Polym. Sci., 120 (2011) 5, 2632-2640, doi:10.1002/app.33494

${ }^{22}$ I. Srikanth, A. Daniel, S. Kumar, N. Padmavathi, V. Singh, P. Ghosal, A. Kumar, G. R. Devi, Nano silica modified carbon-phenolic composites for enhanced ablation resistance, Scripta Mater., 63 (2010) 2, 200-203, doi:10.1016/j.scriptamat.2010.03.052

${ }^{23}$ M. Atarian, H. R. Salehi, M. Atarian, A. Shokuhfar, Effect of oxide and carbide nanoparticles on tribological properties of phenolic-based nanocomposites, Iran. Polym. J., 21 (2012) 5, 297-305, doi:10.1007/s13726-012-0038-X

${ }^{24}$ M. Nakada, Trends in engine technology and tribology, Tribol. Int., 27 (1994) 1, 3-8, doi:10.1016/0301-679X(94)90056-6

${ }^{25} \mathrm{P}$. H. Kang, H. S. Yang, Preparation of SiC/C composite sheet from polycarbosilane/carbon-based resin mixture, Korean. J. Chem. Eng., 15 (1998) 6, 580-584, doi:10.1007/BF02698981

${ }^{26}$ J. H. Koo, L. A. Pilato, G. E. Wissler, Polymer nanostructured materials for propulsion systems, J. Spacecraft Rockets, 44 (2007) 6 , 1250-1262, doi:10.2514/1.26295

${ }^{27}$ G. Zhou, S. Movva, L. J. Lee, Nanoclay and long-fiber-reinforced composites based on epoxy and phenolic resins, J. Appl. Polym. Sci., 108 (2008) 6, 3720-3726, doi:10.1002/app.27886

${ }^{28}$ Physical Properties Of Methanol: $\mathrm{CH}_{3} \mathrm{OH}$, Cetiner Engineering Corporation (CEC Database), http://www.cetinerengineering.com/ Properties.htm, 6.12.2015

${ }^{29}$ European Standard SR EN ISO 527: Plastics - Determination of tensile properties, 2003 


\section{MATERIALI IN TEHNOLOGIJE/MATERIALS AND TECHNOLOGY (1967-2017) - 50 LET/50 YEARS}

\section{G. PELIN et al.: MECHANICAL AND TRIBOLOGICAL PROPERTIES OF NANOFILLED PHENOLIC-MATRIX ...}

${ }^{30}$ European Standard SR EN ISO 14125 Fibre-reinforced plastics composites - Determination of flexural properties, 2001

${ }^{31}$ P. S. Parameswaran, Modification of phenol formaldehyde resin for improved mechanical properties, PhD. Thesis, Department of Polymer Science \& Rubber Technology, Cochin University of Science and Technology, India, 2010

${ }^{32}$ J. M. Perez, J. M. Echeverria, M. Oliet, M. V. Alonso, F. Rodriguez, Characterization of a novolac resin substituting phenol by ammonium lignosulfonate as filler or extender BioResources, 2 (2007) 2, 270-283

${ }^{33}$ S. Janz, Amorphous silicon carbide for photovoltaic applications, Masters Thesis, Fakultät für Physik, Universität Konstanz, Freiburg, 2006

${ }^{34}$ P. V. Prabhakaran, K. J. Sreejith B. Swaminathan, S. Packirisamy, K. N. Ninan, Silicon carbide wires of nano to sub-micron size from phenolfurfuraldehyde resin, J. Mater. Sci., 44 (2009) 2, 528-533, doi:10.1007/s10853-008-3087-y
${ }^{35}$ G. Pelin, C.-E. Pelin, A. Ştefan, I. Dincă, A. Ficai, E. Andronescu, R Truşcă, Influence of nanometric silicon carbide on phenolic resin composites properties, Bulletin of Materials Science, 39 (2016) 3, 769-775, doi:10.1007/s12034-016-1185-z

${ }^{36}$ B. S. Hayes, L. M. Gammon, Optical Microscopy of Fiber-Reinforced Composites, ASM International, Ohio, 2010

${ }^{37}$ J. K. Lancaster, The effect of carbon fibre reinforcement on the friction and wear of polymers, J. Phys. D: Appl. Phys., 1 (1968) 5, 549-559, doi:10.1088/0022-3727/1/5/303

${ }^{38}$ N. Subramaniam, B. R. Sinha, F. D. Blum, Y.-R. Chen, L. R. Dharani, Glass fiber based friction materials, International Journal of Polymeric Materials and Polymeric Biomaterials, 15 (1991) 2 , 93-102, doi:10.1080/00914039108031526 